\title{
Wine through the Eyes of Two Generations
}

DOI 10.18267/pr.2021.krn.4816.23

\author{
Dana Vokounová \\ ORCID iD: 0000-0002-9963-8658 \\ dana.vokounova@euba.sk \\ University of Economics in Bratislava, Faculty of Commerce, Department of \\ Marketing, \\ Bratislava, Slovakia
}

\begin{abstract}
Wine is a specific product in which the consumer expects an extended level of satisfaction. This applies to such characteristics as the quality of the wine, the variety, its balance, the enjoyment of its consumption. That is why consumers often pay attention to things such as the brand image, the wine-growing region, the year of production or awards from prestigious exhibitions when choosing this type of product. The aim of this paper is to identify important factors when choosing a wine, and develop recommendations for small winery Alora regarding generational-based segmentation. The study revealed that members of Generation $Y$ drink wine more often, they like modern labels and the label of the Alora winery attracted them more than Generation X. Generation X looks like a suitable target group because it appreciates the domestic origin, wine-growing area, and other factors, which a small winery meets or can adapt to.
\end{abstract}

Keywords: wine, generation, label, small winery

JEL Classification codes: M11

\section{INTRODUCTION}

With the abundance of wine on the global market the wine industry has become strongly competitive. Increasing competition has resulted in shifts in wine consumption patterns (Hussain et al., 2008). There are two important reasons for segmenting wine market. First, segmentation helps in analyzing the needs of a particular customer segment and second, the results will allow marketing to focus on these identified needs (Barber et al., 2008). With this in mind, a research study was designed to identify the differences among Generations $X$ and $Y$ in perceptions, preferences and behaviors towards wine, as well as differences in the evaluation of the bottle label of small Slovak winery Alora. The study's objectives are to identify important factors when choosing a wine, and develop recommendations for small winery regarding generational-based segmentation.

\section{LITERATURE REVIEW}

Wine is a product with an immediate effect on the consumer and a high level of differentiation, so customer orientation is a fundamental determinant of the competitive advantage of a winery (Muňo et al., 2019). However, wine as an alcoholic beverage is subject to various restrictions and regulations, such as marketing communication or the age of the target group. Because of the high level of product differentiation, consumers vary in their preferences regarding wine attributes (Mauracher et al., 2019). A survey carried out by Vitis winery in 2019 showed that taste is the most important factor in choosing a wine, followed by the price, brand, country of 
origin, grape variety, wine color, type of bottle closure, label, and type of bottle. Only a very small group of respondents consider Awards as important (Retail magazine.sk). Most Slovaks drink wine at least once a month, especially dry white wine (Vitis). Generation Y, compared to Generation $X$, does not need special occasions such as celebrations or dinners in restaurants. The generation $Y$ also drinks wine at home while cooking, watching movies or reading a book, because it is more comfortable, cheaper and more personal (Kadlec, 2020). In the USA, one of the most promising new demographic segment is Generation $Y$ (Thach \& Olsen, 2006). This group has shown an interest in wine at an early age, and they appreciate most those wines that are fun and approachable (Wagner et al., 2011). But the analysis of data for the years 2017-2019 on wine sales showed that Generation Xers spent more than other generations, so this generation is a key demographic that wine marketers must not overlook (Forbes, 2020). However, ethical consumerismus has became a mainstream and younger consumers are increasingly paying attention to the impact of their behavior. Companies must therefore act responsibly and present it on wine labels (Wine intelligence, 2019). The main trends in wine industry include organic wines made from grapes grown in accordance with principles of eco farming, orange wines made by fermenting grapes with skins and seeds in grape juice, rosé wines and alternative packaging innovations, e. g. cans (Errand Pro, 2020). A Chilean study showed, that higher levels of consumer trust in a wine brand is related to brand satisfaction, but not necessarily with brand loyalty directly (Bianci, 2015). This is also confirmed by knowledge of the US wine market, for which it is typical that most wine consumers buy an assortment of different wines and brands. Typically, they have one wine considered as their "house wine", However, for other purchases they do not have much brand loyalty (Moulton \& Lapsley, 2001). With increasing competition and consumer demands, wine producers have to follow trends in the wine market. Marketing based on positive emotions is becoming more and more popular. Producers can organize visits in vineyards and wineries, wine festivals or wine events (Asero \& Patti, 2016). Changing taste and new preferences among consumers, along with increasing demand for new and exotic flavors are expected to fuel the growth of the wine market as well (Mordor Intelligence, 2020).

\section{METHODOLOGY}

This research uses an on-line survey instrument that was administered through the use of a CAWI. The questionnaire comprised three sections. The first section asked respondents for general wine consumption habits, wine preferences and importance of factors in choosing wine. The second section measured evaluation of the label of small winery Alora. The third section collected general demographic information. The questionnaire was available on the Google website and distributed through social networks in March 2020. The sample was not drawn randomly, so the results cannot be generalize to any specific population. Data were analyzed using descriptive techniques and results were cross-tabulated and $\chi^{2}$ - test was used to test the independence between Generations $X$ and $Y$. Generation X was represented by people born between 1961 and 1980 and Generation $Y$ between 1981 and 2000. In total, 221 answers were collected, and 188 of them were from wine consumers. Both generations of wine consumers were equally represented $\left(n_{\text {XorY }}=94\right)$ and $43 \%$ of the sample was male $(41,5 \%$ Gen Xers and 44,3\% from Gen Yers). 


\section{RESULTS AND DISCUSSION}

\subsection{Wine in general}

In this section, we will present the results of the survey that relates to attitudes of both Generations to wine.

\section{Frequency of drinking wine}

Generations $X$ and $Y$ differ significantly in the frequency of wine drinking (Tab. 1). We can say that Generation $Y$ drinks wine more often, at least several times a month, and Generation $X$ less often. But on the other hand, those who do not drink wine at all have a larger share of Generation Y (almost a fifth).

Tab. 1 Frequency of drinking wine (\%)

\begin{tabular}{|l|c|c|}
\hline & \multicolumn{2}{|c|}{ Generation } \\
\hline & $\mathrm{X}$ & $\mathrm{Y}$ \\
\hline several times a week & 10,9 & 18,3 \\
\hline several times a month & 20,6 & 29,6 \\
\hline less often & 56,8 & 33,9 \\
\hline not at all & 11,8 & 18,3 \\
\hline & \multicolumn{2}{|c|}{ sig. level $=0,05$} \\
\hline
\end{tabular}

Source: author's survey

Only those respondents who drink wine at least occasionally answered the remaining questions, 94 from both generations ( $\left.\mathrm{n}_{\text {total }}=188\right)$.

\section{Knowledge of wine}

In the next question, we asked the respondents how they would characterize themselves in terms of knowledge of wine. Both generations responded very similarly (Table 2 ). This confirms cross-cultural study findings about very weak generational effect for wine involvement (Mueller et al., 2011). A quarter of respondents from both generations characterize themselves as wine experts who care about the quality, almost three quarters have only some information about wine and are only interested in the taste of wine, and only a very small portion of respondents said they knew nothing about wine.

Tab. 2 Knowledge of wine (\%)

\begin{tabular}{|l|c|c|}
\hline & \multicolumn{2}{|c|}{ Generation } \\
\hline & $\mathrm{X}$ & $\mathrm{Y}$ \\
\hline I'm just interested in the taste & 71,3 & 74,5 \\
\hline I care about the quality of the wine & 25,5 & 23,4 \\
\hline I know nothing about wine & 3,2 & 2,1 \\
\hline
\end{tabular}

Source: author's survey 


\section{Wine preferences}

Although both generations drink white and red wine, Generation $X$ prefers red wine and Generation Y prefers white (approximately $40 \%$ ) and nearly $15 \%$ of them drink rosé (Tab. 3). Both generations clearly prefer Slovak wines, but Generation $Y$ is also more open to foreign ones.

Tab. 3 Wine preferences (\%)

\begin{tabular}{|l|c|c|l|c|c|}
\hline & \multicolumn{2}{|c|}{ Generation } & & \multicolumn{2}{c|}{ Generation } \\
\hline \multicolumn{1}{|c|}{ color } & $\mathrm{X}$ & $\mathrm{Y}$ & \multicolumn{1}{c|}{ origin } & $\mathrm{X}$ & $\mathrm{Y}$ \\
\hline white & 30,2 & 39,6 & Slovak & 73,6 & 66,7 \\
\hline red & 40,6 & 26,1 & foreign & 14,2 & 27,0 \\
\hline rosé & 2,8 & 14,4 & no preferences & 12,2 & 6,3 \\
\hline no preferences & 26,4 & 19,8 & & & \\
\hline & \multicolumn{2}{|c|}{ sig. level $=0,00$} & & \multicolumn{2}{c|}{ sig. level $=0,07$} \\
\hline
\end{tabular}

Source: author's survey

\section{Loyalty}

We were also interested in loyalty to the producers, resp. brands, and we found out that the two generations do not differ significantly and more than half of them like to test different producers (Tab. 4). Only a very small number of respondents are loyal to one producer, and more than a third have a few favorite producers. However, most of them like to try wine from different producers.

Tab. 4 Loyalty (\%)

\begin{tabular}{|l|c|c|}
\hline & \multicolumn{2}{|c|}{ Generation } \\
\hline & $\mathrm{X}$ & $\mathrm{Y}$ \\
\hline one favourite & 2,8 & 8,1 \\
\hline several favourite & 35,8 & 36,0 \\
\hline like to taste different & 61,4 & 55,8 \\
\hline
\end{tabular}

Source: author's survey

\section{Factors in choosing wine}

We asked two questions when determining the importance of factors in choosing wine. With the first question, we focused on what they notice first when choosing a wine. They were able to choose only one of the factors. In the second question, respondents answered on a scale of 1 to 5 for each factor ( $1=$ very important $5=$ not important). To the factors from the first question, we added another, namely the type of closure such as cork or screw caps (Tab. 5).

The survey showed that there are 2 main factors in choosing wine, namely the amount of residual sugar and wine color (both questions confirmed this). Although there are no significant differences between the two generations in what they notice first, Generation X nevertheless pays more attention to wine-growing area and Generation $Y$ to price (Fig. 1). The results correspond to the results of a Boomer Generation Wine Consumers survey which showed that 
Generation X cares more about wine producer and quality and will typically spend more money to purchase it (Wolf et al., 2005).

In the second question concerning preferences, we used contingency tables and $\chi^{2}$-Goodness of fit test to find out whether there are significant differences between the two generations in the importance they relate to the factors examined when choosing wine. Compared to Generation $Y$, the more important (but not the most important) factors for Generation X are: sparkling (sig. Level $=0.01$ ), country of origin (sig. Level $=0.05$ ), wine-growing area (sig. Level $=0,00$ ), awards from exhibitions (sig. Level $=0,03$ ) and type of bottle closure (sig. Level $=0,00$ ). These results are similar to the research conducted in Portugal (Tavares \& Azevedo, 2011) where factors like country of origin or awards are more important for Generation X.

Tab. 5 Factors in choosing wine

\begin{tabular}{|l|c|c|c|c|}
\hline & \multicolumn{2}{|c|}{ Noticed as first } & \multicolumn{2}{c|}{ Importance } \\
\hline & \multicolumn{2}{|c|}{$\%$} & \multicolumn{2}{c|}{ average } \\
\hline & Generation X & Generation Y & Generation X & Generation Y \\
\hline sweetness & 27,4 & 23,4 & 1,79 & 2,00 \\
\hline color & 19,8 & 18,9 & 1,92 & 1,83 \\
\hline country of origin & 11,3 & 14,4 & 2,30 & 2,62 \\
\hline wine-growing area & 11,3 & 5,4 & 2,43 & 3,16 \\
\hline appearance of bottle or label & 10,4 & 9,9 & 2,50 & 2,63 \\
\hline grape variety & 8,5 & 5,4 & 2,44 & 2,60 \\
\hline price & 5,7 & 12,6 & 2,28 & 2,24 \\
\hline awards & 2,8 & 1,8 & 2,54 & 3,06 \\
\hline year of production & 2,8 & 5,4 & 2,75 & 3,03 \\
\hline bottle volume & 0 & 1,8 & 3,05 & 2,97 \\
\hline sparkling & 0 & 0,9 & 2,03 & 2,59 \\
\hline closure & & & 2,56 & 2,78 \\
\hline
\end{tabular}

Source: author's survey

Fig. 1 Noticed as first (\%)

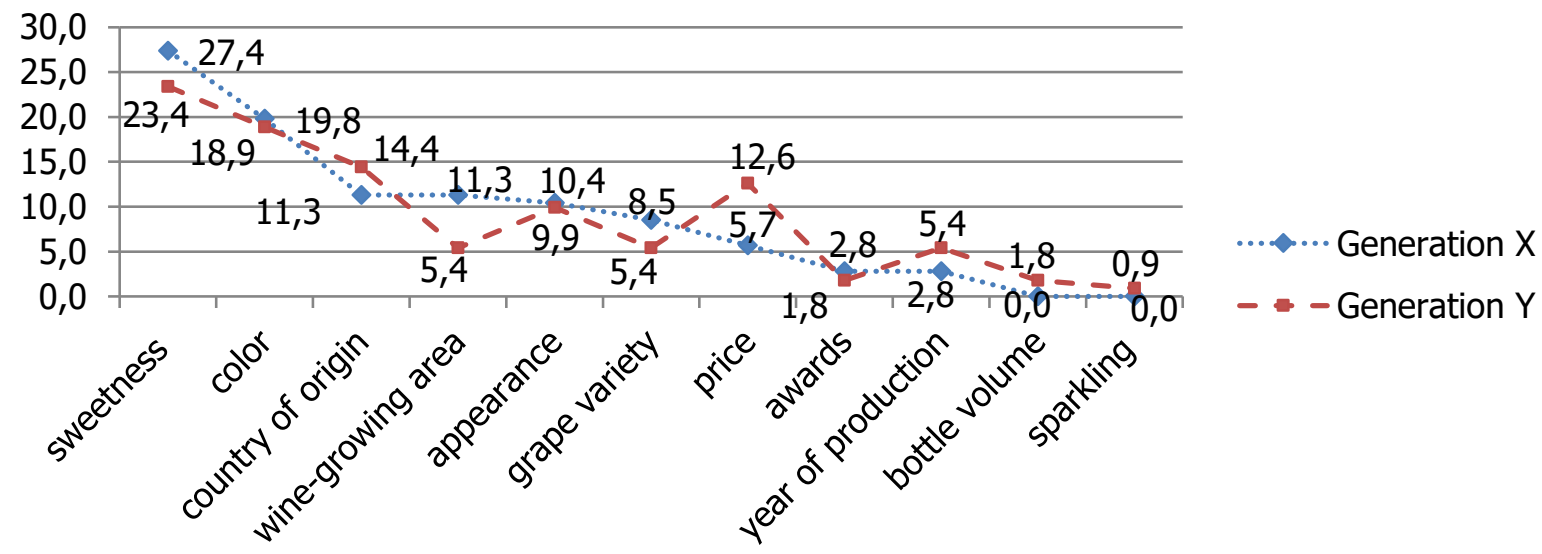

Source: author's survey 
To make it easier to show the importance of individual factors, we decided to present the average of the scale (1 - 5) for each factor instead of contingency tables (Fig. 2). The 5 most important factors when choosing a wine are for Generation X sweetness and color of wine, sparkling, price and country of origin and for Generation $Y$ color and sweetness of wine, price, sparkling and grape variety.

Fig. 2 Factor importance ( $1=$ very, $5=$ not $)$

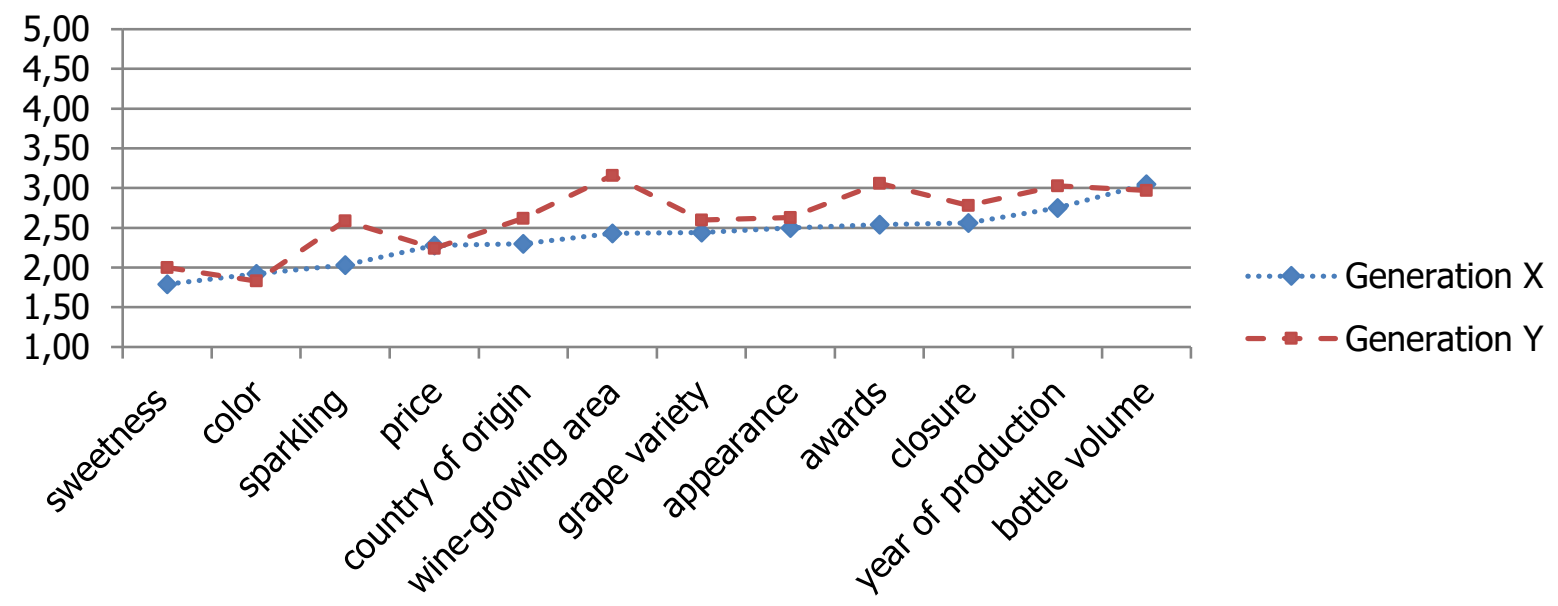

Source: author's survey

\section{Price}

We asked the respondents how much they are willing to spend on a bottle of wine when they buy it for their own consumption and how much when they buy it as a gift. When buying wine for own consumption, more than half of Generation $X$ is willing to pay 5 to 10 euros and less than a third 3 to 5 (Tab. 5). Generation $Y$ is more inclined to a lower price, almost half are used to buying wine for 3 to 5 euros, more than a third from 5 to 10 euros.

Tab. 5 Price for bottle of wine (\%)

\begin{tabular}{|l|c|c|c|c|}
\hline & \multicolumn{2}{|c|}{ own consumption } & \multicolumn{2}{c|}{ gift } \\
\hline & Generation $X$ & Generation $Y$ & Generation X & Generation $Y$ \\
\hline less than $3 €$ & 0,0 & 5,4 & 0,0 & 0,0 \\
\hline $3,01-5 €$ & 31,1 & 45,0 & 2,8 & 10,8 \\
\hline $5,01-10 €$ & 55,7 & 37,8 & 52,8 & 55,9 \\
\hline $10,01-18 €$ & 13,2 & 9,9 & 37,7 & 25,2 \\
\hline more than $18 €$ & 0,0 & 1,8 & 6,6 & 8,1 \\
\hline & \multicolumn{2}{|c|}{ sig. level $=0,00$} & \multicolumn{3}{c}{ sig. level $=0,05$} \\
\hline
\end{tabular}

Source: author's survey

In the case of buying wine as a gift, both generations are willing to pay more (Tab. 5). The share of both generations increased significantly at a price of 10 to 18 euros. Generation X does not buy wine cheaper than 5 euros or more expensive than 18. More than half of them buy wine for 5 to 10 euros and more than a third for 10 to 18 euros. In Generation Y, the 
share of those who would buy wine for 3 to 5 euros decreased significantly and the share of those who are willing to pay more than 5, resp. 10 euros.

Both generations are willing to pay more for wine if they buy it as a gift. It can be stated that Generation $X$ buys wine at a higher price than Generation $Y$. This corresponds to the result of a survey conducted in California: Generation $Y$ consumers want inexpensive wines that they believe represent a good value (Wolf et al., 2005).

\section{Label}

We asked respondents which labels they liked more. The differences between the generations are significant (sig. Level $=0.00$ ). The younger Generation $Y$ clearly tends to modern labels or does not care about the appearance of the label. The older Generation $\mathrm{X}$ is not entirely distinct, but likes modern labels the least (Fig. 3).

\section{Fig. 3 Label preference}

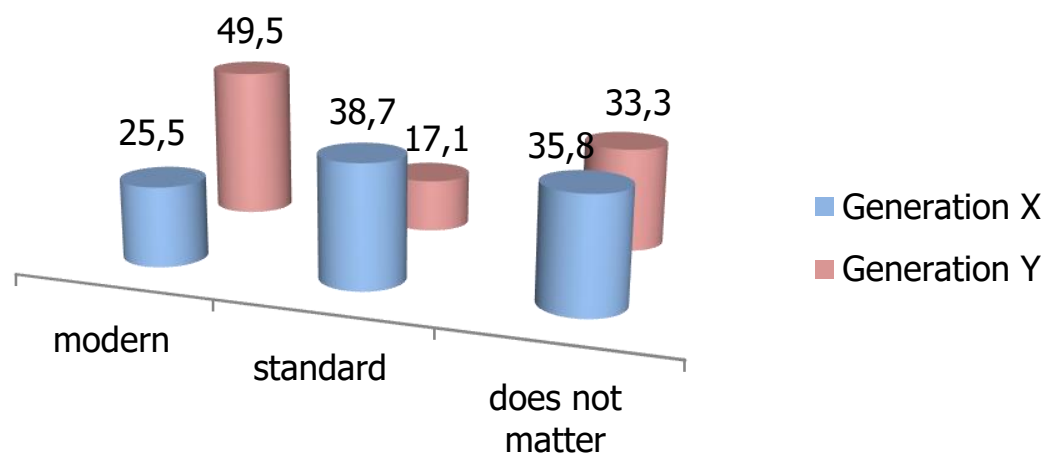

Source: author's survey

\section{Label of small winery Alora}

Wine Alora is a product of a small family winery. All Alora wines are unfiltered, processed by hand, without the use of modern technology, without additives and produced in limited quantities. Wine is packed in dark or clear glass bottles and closed with a cork.

Fig. 4 Labels of the wine Alora
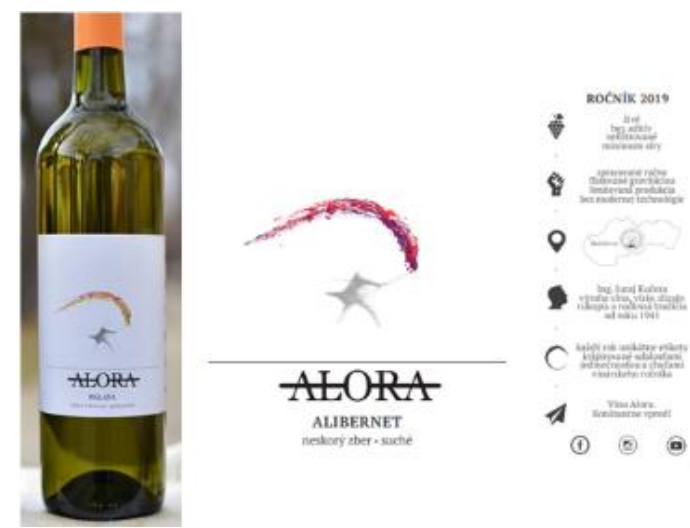

Source: Winery Alora 
The logo and simplicity of the label were 2 factors which attracted immediate attention of both generations (Tab. 6).

Tab. 6 Attraction (\%)

\begin{tabular}{|l|c|c|}
\hline & \multicolumn{2}{|c|}{ Generation } \\
\hline & $\mathrm{X}$ & $\mathrm{Y}$ \\
\hline logo & 54,7 & 48,7 \\
\hline simplicity & 36,8 & 36,5 \\
\hline colors & 5,7 & 9,6 \\
\hline nothing & 2,8 & 1,7 \\
\hline other & 0,0 & 3,5 \\
\hline
\end{tabular}

Source: author's survey

Fig. 5 Evaluation of the label (average)

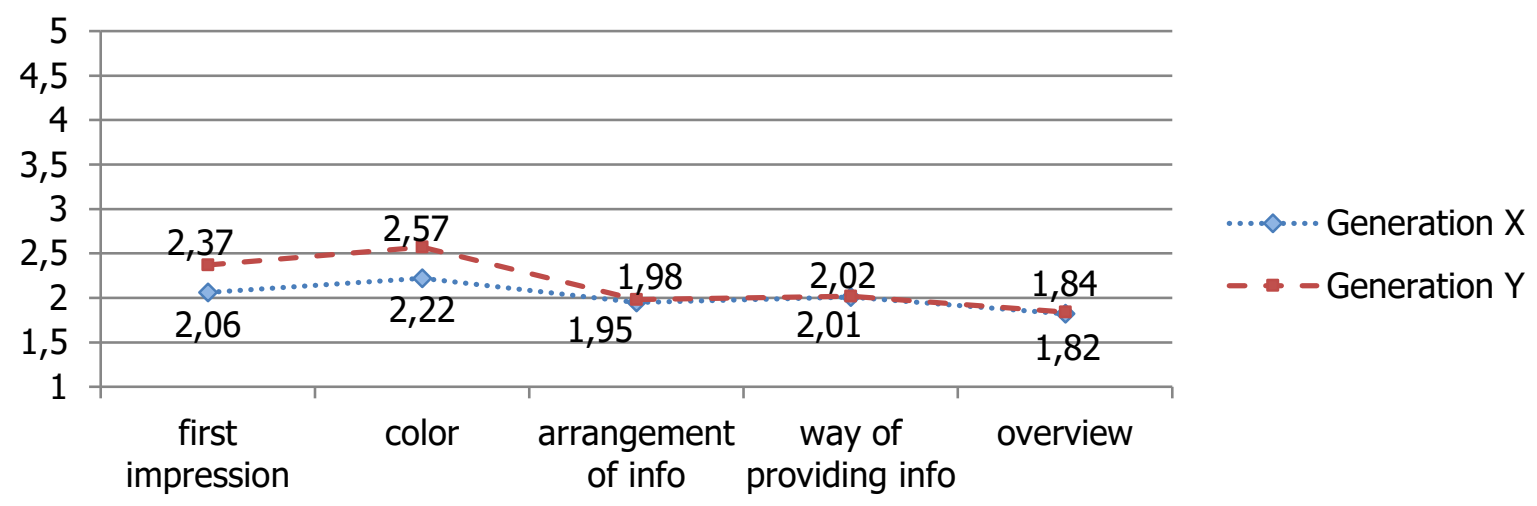

Source: author's survey

Furthermore, the respondents had to evaluate on a scale from 1 to 5 ( $1=$ like a lot, $5=$ don't like at all) criteria such as first impression, colors on the label, arrangement and way of providing information and overview of the information. Using contingency tables and $\chi 2$ Goodness of fit, we found that compared to Generation Y, Generation X evaluates better the first impression and color of the label (sig. Level $=0.05$ ) and the other criteria evaluates the same. To make it easier to display the evaluation of individual criteria, we decided to present the average of the scale ( 1 - 5) for each criterion instead of contingency tables (Fig. 5).

Most respondents like the label, $72.6 \%$ of Generation X and $71.3 \%$ of Generation Y. We noticed significant differences (sig. Level $=0.01$ ) in the perception of label color. Two thirds of Generation $Y$ like this label (64.3\%) and more than half of Generation X perceive it as indistinct and would use more colors (52.8\%).

\section{CONCLUSION}

The results of the survey showed that wine is one of the favorite drinks of both generations, while most consumers are not wine experts. Both white and red wines are popular, but Generation $\mathrm{X}$ is more inclined to red. Consumers prefer Slovak wines, but Generation $\mathrm{Y}$ is also more open to drink foreign wines. Both generations like to alternate wine from different 
producers. When choosing wine, 2 factors are important for them, namely the amount of residual sugar and wine color, while Generation $X$ also evaluates sparkling, country of origin, wine-growing area, awards from exhibitions and Generation $Y$ notices the price. The sensitivity to the price of Generation $Y$ has also been shown in the fact that it buys wine at a lower price than Generation X. Both generations are willing to pay more for wine if they buy it as a gift. There are significant differences between the two generations in what labels they like, and logically Generation Y clearly tends to modern labels. The results of the survey indicated that it makes sense to segment and analyze the wine market from the point of view of generations. The differences between the two generations can be used in marketing or communication activities of wine producers.

As far as the Alora brand is concerned, Generation X looks like a suitable target group because it appreciates the domestic origin, wine-growing area, awards from exhibitions and the type of bottle closure, which a small winery meets or can adapt to. This Generation is also willing to accept the higher price that a small producer wine usually has. But on the other hand, Generation $Y$ is looking for experiences, likes to experiment and learn new things. This opens up space for the creativity of wine producer, which can offer non-traditional tastes and experiences. Games and apps are the perfect way to experiment, have fun, and share unusual experiences.

A limitation of this study is that answers have been obtained by non-probability method, namely by convenience sampling. As opposed to a random sample, the results may not be used to make an inference about the whole population of wine consumers in Slovakia. However, thanks to the growth of internet use among Slovak people of different age, we believe that our study may provide insight into attitudes of Generations X and Y. Opportunities for future research would be to consider other factors when choosing wine such as brand image, brand loyalty or promotional offer. This study could be also replicated to compare behavior and preferences of other generations.

\section{ACKNOWLEDGEMENT}

This paper originated as the result of working on the grant scheme VEGA (S.G.A.) No. 1/0657/19 The role of influencers in the consumer decision-making process.

\section{REFERENCES}

Asero, V., \& Patti, S. (2016). Wine Tourism Experience and Consumer Behavior: The Case of Sicily. Tourism Analysis, 16(4), 431-442. https://doi.org/10.3727/ $108354211 \times 13149079788936$

Barber, N., Dodd, T., \& Ghiselli, R. (2008). Capturing the Younger Wine Consumer. Journal of Wine Research, 19(2), 123-141. https://doi.org/10.1080/09571260802622225

Bianci, C. (2015). Consumer Brand Loyalty in the Chilean Wine Industry. Journal of Food Products Maketing, 21(4), 442-460. https://doi.org/10.1080/10454446.2014.885859

Errand Pro. (2020). Wine Market Trends for 2020. Retrieved 24 January 2021, from https://www.errandpro.eu/2020/02/06/wine-market-trends-for-2020/

Forbes. (2020). Millenials maybe, but new data direct the wine industry to Gen X. Retrieved 14 January 2021, from https://www.forbes.com/sites/thomaspellechia/2019/08/23/ millennials-maybe-but-new-data--direct-the-wine-industry-to-gen-x/?sh=33d5840216a3 
Hussain, M., Cholette, S., \& Castaldi, R. M. (2008). An Analysis of Globalization Forces in the Wine Industry. Journal of Global Marketing, 21(1), 33-47. https://doi.org/10.1300/J042v21n01_04

Kadlec, J. (2020). Ako mileniáli menia kultúru pitia a vinársky biznis. Retrieved 02 February 2021, from https://innovations.sk/mileniali-a-vino-ako-mlada-generacia-meni-kulturu-pitia-avinarsky-biznis/

Mauracher, Ch., Procidano, I., \& Valentini, M. (2019). How Product Attributes and Consumer Characteristics Influence the WTP, Resulting in a Higher Price Premium for Organic Wine. Sustainability, 11(15). https://doi.org/10.3390/su11051428

Mordor Intelligence. (2020). Wine market - growth, trends, Covid-19 impact, and forecasts (2021-2026). Retrieved 14 January 2021, from https://www.mordorintelligence.com/ industryreports/ wine-market

Moulton, K., \& Lapsley, J. (2001). Successful Wine Marketing. Springer Science+Business Media New York.

Mueller, S., Remaud, H., \& Chabin, Y. (2011). How strong and generalisable is the Generation $Y$ effect? A cross-cultural study for wine. International Journal of Wine Business Research, 23(2), 125-144. https://doi.org/10.1108/17511061111142990

Muňoz, R. M., Fernández, M. V., \& Salinero, M. Y. (2019). Assessing Consumer Behavior in the Wine Industry and Its Consequences for Wineries: A Case Study of a Spanish Company. Frontiers in Psychology,10. https://doi.org/10.3389/fpsyg.2019.02491

Retail magazin.sk. Čo najviac rozhoduje pri nákupe vína? Retrieved 18 January 2021, from https://www.retailmagazin.sk/spotrebitel/prieskumy/4575-co-najviac-rozhoduje-pri-nakupevina

Tavares, C. \& Azevedo, A. (2011). Generation X and Y Expectations about Wine Tourism Experiences: Duoro (Portugal) versus Napa Valey (USA). In Book of proceedings vol. I International conference on tourism \& management studies (pp. 259-269). Algarve. Retrieved 24 March 2021, from https://www.researchgate.net/search.Search.html?type= publication\&query=GENERATION\%20X\%20AND\%20Y\%20EXPECTATIONS\%20ABOUT\%20W INE\%20TOURISM\%20EXPERIENCES

Thach, E., \& Olsen, J. E. (2006). Market Segment Analysis to Target Young Adult Wine Drinkers. Agribusiness, 22(3), 307-322. https://doi.org/10.1002/agr.20088

Vitis. (2020). Chcete vyberat' víno ako profík? Retrieved 18 January 2021, from https://www.vitis.sk/chcete-vyberat-vino-ako-profik/

Wagner, P., Olsen, J., \& Thach, L. (2011). Wine Marketing \& Sales; Success Strategies for a Saturated Market. San Francisco : Board and Bench Publishing.

Wine intelligence. (2019). Global Trends in Wine: The Who, What and How. Retrieved 25 January 2021, from https://www.wineintelligence.com/global-trends-in-wine-the-who-whatand-how/

Wolf, M. M., Carpenter, S., \& Qenani-Petrela, E. (2005). A Comparison of X, Y, and Boomer Generation Wine Consumers in California. Retrieved 18 January 2021, from https://ageconsearch.umn.edu/record/26724/ 